\title{
De la órbita de la generación del 27 al surrealismo. El caso de Íntimo ser de José María de la Rosa
}

\author{
José Manuel Martín Fumero
}

Martín Fumero, J. M. (2021). De la órbita de la generación del 27 al surrealismo. El caso de Íntimo ser de José María de la Rosa. Revista de Filología y Lingüística de la Universidad de Costa Rica, 47(2), e46571. doi: https://doi.org/10.15517/rfl.v47i2.46571

\section{(9) $(1) \Theta \Theta$}

Doi: https://doi.org/10.15517/rfl.v47i2.46571

URL: https://revistas.ucr.ac.cr/index.php/filyling/index 
Revista de Filología y Lingüística de la Universidad de Costa Rica

ISSN: 0377-628X

ISSN: 2215-2628

filyling@gmail.com

Universidad de Costa Rica

Costa Rica

\title{
De la órbita de la generación del 27 al surrealismo. El caso de Íntimo ser de José María de la Rosa
}

\author{
Martín Fumero, José Manuel \\ De la órbita de la generación del 27 al surrealismo. El caso de Íntimo ser de José María de la Rosa \\ Revista de Filología y Lingüística de la Universidad de Costa Rica, vol. 47, núm. 2, e46571, 2021 \\ Universidad de Costa Rica, Costa Rica \\ Disponible en: http://www.redalyc.org/articulo.oa?id=33266553007 \\ DOI: https://doi.org/10.15517/rfl.v47i2.46571
}

\section{(c) $(1) \Theta(\Theta$}

Esta obra está bajo una Licencia Creative Commons Atribución-NoComercial-SinDerivar 3.0 Internacional. 


\title{
De la órbita de la generación del 27 al surrealismo. El caso de Íntimo ser de José María
} de la Rosa

\section{From the Orbit of the Generation of 27 to Surrealism. The Case of Intimate Being by José María de la Rosa}

José Manuel Martín Fumero

Centro de Educación a Distancia Santa Cruz de Tenerife

Mercedes Pinto, Santa Cruz,Tenerife, España

jmarfum@gobiernodecanarias.org

(iD https://orcid.org/0000-0003-4324-6003

\author{
DOI: https://doi.org/10.15517/rfl.v47i2.46571 \\ Redalyc: http://www.redalyc.org/articulo.oa?id=33266553007
}

Recepción: 05 Mayo 2020

Aprobación: 29 Junio 2020

\section{RESUMEN:}

José María de la Rosa es uno de los autores de la lírica insular de vanguardia cuya evolución escritural, al igual que otros autores coetáneos como Agustín Espinosa, Domingo López Torres, Emeterio Gutiérrez Albelo o Pedro García Cabrera, partió de la estética última, la del 27, hasta el surrealismo. Este artículo pretende asediar críticamente su obra primera, Íntimo ser (1936), poemario apenas estudiado y de cuyo contenido apenas hay referencias. Realizaremos un análisis de crítica textual a partir de los textos originales publicados por el autor, estudiando tanto sus aspectos temáticos como expresivos, en aras de relacionarlo con los autores anteriormente citados, amén de con otros nombres del 27 cuya lectura nutrió su proceso creativo. Como resultados, podrá apreciarse que la estética del 27 supuso un aprendizaje necesario para, finalmente, desembocar en el torrente surrealista.

Palabras Clave: crítica literaria, lírica, José María de la Rosa, generación del 27, Íntimo ser.

\section{Abstract:}

José María de la Rosa is one of the authors of the avant-garde island lyric whose scriptural evolution, like other contemporary authors such as Agustín Espinosa, Domingo López Torres, Emeterio Gutiérrez Albelo or Pedro García Cabrera, started from the last aesthetic, that of 27, up to surrealism. This article aims to critically besiege his first work, Intimate Being (1936), a poetry book hardly studied and of whose content there are hardly any references. We will carry out an analysis of textual criticism based on the original texts published by the author, studying both its thematic and expressive aspects, in order to relate it to the aforementioned authors, amen with other names from 27 whose reading nurtured his creative process. As a result, it will be appreciated that the aesthetics of ' 27 was a necessary learning to finally lead to the surreal torrent.

KEYWORDS: literary criticism, lyric, José María de la Rosa, Generation of '27, Intimate being .

\section{INTRODUCCIÓN}

Íntimo ser (1936) constituye la segunda obra del escritor canario José María de la Rosa López Abeleda (1908-1989) a pesar de que, cronológicamente, sea la primera. Por una parte, el propio poeta ha dejado claras pistas de que, desde el punto de vista estructural, compositivo y espiritual, Vértice de sombra es su primer libro poético, siendo la principal de ellas la unidad que presenta este segundo libro en el tiempo (1940) con respecto al que aquí estudiamos. Por otra parte, la presencia de las técnicas y motivos surrealistas está más arraigada en Vértice de sombra, como ya se ha estudiado (Martín Fumero, 2018, pp. 121-137), algo a lo que ayudó, probablemente, el hecho de que José de la Rosa fuese secretario de Gaceta de Arte en los últimos momentos de esta revista, lo que, en parte, motivó que se relacionase con algunos de los poetas más ligados al movimiento surrealista, como Domingo López Torres o Agustín Espinosa. Domingo Pérez Minik (1975, pp. 41-42) cuenta cómo de la Rosa y algunos de sus amigos generacionales se reunían, de manera informal y esporádica, para poner en común sus gustos literarios: 
Ni Pedro García Cabrera, ni Agustín Espinosa, ni Domingo López Torres, ni Emeterio Gutiérrez Albelo, ni José María de la Rosa, el grupo generacional más cumplido de esta erupción lírica, ninguno de ellos sentía el menor aprecio por el "modernismo", ni por los barroquismos tradicionales a lo Góngora, ni por los impresionismos intimistas, ni por Antonio Machado o Miguel de Unamuno. Alguno que otro se consideraba cerca de Juan Ramón Jiménez y su poesía honestamente desnuda de tiempos pasados. Pero estuvieron en los primeros años más cerca de Rafael Alberti, García Lorca y Pedro Salinas, dentro de la inicial posición lúdica de los hombres del 27, con sus nuevas imágenes, sus significados juegos y las subversiones personales en las maneras de entender el mundo, las palabras, el ritmo, entre la estilización más rigurosa y los vulgarismos más escondidos, con los refinamientos más increíbles, y los módulos perdidos entre la abstracción más inocente y la vida más próxima.

Hemos de recordar que, a principios de los años 30, José María de la Rosa era secretario del Ateneo de Santa Cruz, que estaba bajo la presidencia de Agustín Espinosa; y en 1935 sustituye en Gaceta de Arte a Pedro García Cabrera en el puesto de secretario de esta publicación, como ya se ha comentado. En este ambiente asiste, como testigo de excepción, tanto a la exposición sobre Óscar Domínguez que se celebra en el Círculo de Bellas Artes de Tenerife (1933) y, en 1935, a la muestra de arte surrealista celebrada en Tenerife, a la que asisten Andre Breton, Benjamin Perez y Jacqueline Lamba. Ciertamente, de la Rosa se inicia en el mundo de la poesía gracias a su hermano, Julio Antonio de la Rosa, con el que asistía a las tertulias celebradas por el grupo santacrucero Pajaritas de Papel, conjunto de jóvenes con inquietudes artísticas en el que el autor de Vértice de sombra reconoce el nacimiento de un movimiento artístico nuevo en las islas (de la Rosa, 1977, p. 30):

Tengo que dar un poco marcha atrás para situarnos en los años en que comenzaron a dar muestra de vida activa, aquellos hombres -al menos los principales-, que después compusieron la redacción de "Gaceta de Arte". Este tiempo sería el transcurrido desde 1925 al advenimiento de la República. Había por entonces en Santa Cruz un grupo de jóvenes, -muy jóvenes-, escritores que componen "Pajaritas de Papel”.

A estas afirmaciones añade lo siguiente:

Casi todos los hombres que primitivamente formaron las filas de "Pajaritas de Papel”, continuaron sus lecturas y jamás le perdieron la cara al tiempo en que vivían. Por el contrario fueron cobrando lentamente posiciones más y más actuales, especialmente por sus contactos con el extranjero; hasta que los viajes por Francia y Alemania de Eduardo Westerdahl, pusieron en marcha la idea de crear una revista de alto contenido intelectual, y esta fue "Gaceta de Arte". Nació su primer número en 1932. Y la compusieron autodidactas y universitarios. Su primer cuadro de redacción estaba formado por Eduardo Westerdahl como director y Domingo Pérez Minik, Francisco Aguilar, José Arozena Paredes, Óscar Pestana, Domingo López Torres y Pedro García Cabrera, como redactores, ocupando este último la secretaría de redacción. Tres años más tarde entramos en “Gaceta”, Agustín Espinosa García, Emeterio Gutiérrez Albelo y el que esto escribe, que desempeñó la secretaría de redacción. Se alejaron de la revista por diferentes causas, José Arozena Paredes, Óscar Pestana y Francisco Aguilar (de la Rosa, 1977, p. 30).

El ambiente de Gaceta de Arte le permitió entrar en contacto con el denominado núcleo surrealista de la revista, con quienes charlaba y compartía gustos literarios. Este hecho, sin duda, le permitió abrir sus propios horizontes creativos, además de vencer su reconocida timidez (de la Rosa, 1977, p. 30):

López Torres poseía por aquel entonces -1935, 1936- una librería-estanco que se llamaba Número 5, donde nosotros satisfacíamos nuestros más caros vicios: los libros y el tabaco. Reunidos en tertulia vespertina muchos amigos: Jesús Pérez, Pepe Yanes, Miguel Martín, Ortiz Rosales, Agustín Espinosa, Domingo Pérez Minik, Perico García Cabrera y el que esto escribe (estos últimos pertenecientes a Gaceta de Arte, revista internacional de cultura entonces en su mayor apogeo), charlábamos amistosamente, pero donde no faltaba la polémica por la disparidad de ideas e ideales. Se hablaba mucho de política y otro tanto de la literatura actual. El 27 y el 98 constituían la parcela española; se hablaba mucho, también, del surrealismo francés. Y se dibujaban influencias de Breton, Eluard, Artaud, Tzara y tantos otros. Por lo general, la espada de fuego del surrealismo nos había atravesado mortalmente: su estilo, su escuela, su placer erótico. Domingo y yo coincidíamos en los gustos poéticos, y en su casa adquirí los mejores poemas que poseo, tanto de los franceses como del 27 español.

El grupo surrealista canario encontró, pues, en Gaceta de Arte, un lugar en el que desarrollar sus inquietudes artísticas a la luz del ideario bretoniano con un alto grado de pureza. Esa pureza surrealista se puede ver en las peculiares y personales voces de sus representantes más expresionistas, como Espinosa o López Torres, 
o bien con un planteamiento que es el que más se acerca a la escritura automática, como es el ejemplo de Dársena con despertadores (1936/1987), de García Cabrera. En esta órbita creativa se mueve la obra primera de José de la Rosa, que en gran medida estuvo en un segundo plano en relación con la algarabía que supuso la actividad surrealista en Tenerife, pues tanto su timidez como la humildad que sentía ante su propia actividad como poeta, que, incluso, se traducía en verdadero pavor si se trataba de compartir las composiciones que creaba, suponían un importante freno a la hora de hacer pública su labor poética, pues sentía que daba algo de sí mismo, un pedazo de su vida. Así lo expresaba el propio poeta (de la Rosa, sección "Autobiografía y Justificación”, 1966, párr. 1):

He pasado la mejor y mayor parte de mi vida, esperando. Esperando, no sé qué. Pero esperando. Ahora pongo fin a un deseo muy antiguo, escribiendo estas líneas que acompañarán a mi libro. Un extremoso sentido -mezcla de temor al ridículo y timidez- ha agarrotado siempre mis decisiones; y muchas veces, las más, conducidas al rincón del silencio. Tal ha sido de rígida mi propia censura. Es inexplicable cómo me atrevo a suscribir estos renglones, confesándolo. De verdad, me cuesta gran trabajo.

Así, pues, los poemas de esta obra de juventud encajarían perfectamente dentro del conjunto de obras que apuntalan la primera hora vanguardista en Canarias, como son Índice de las horas felices (1927), de Félix Delgado; Versos y estampas (1927), de Josefina de la Torre; Líquenes (1928), de Pedro García Cabrera; Diario de un sol de verano (1929), de Domingo López Torres; Lancelot 28-7(1929), de Agustín Espinosa; Stadium (1930), de Ramón Feria; Campanario de la primavera (1930), de Emeterio Gutiérrez Albelo; o Tratado de las tardes nuevas (1931), de su hermano Julio Antonio de la Rosa. Todas estas obras suponen un intento por aclimatar los últimos vientos renovadores llegados del ámbito peninsular, y que estaban representados en el legado incipiente de los autores del 27, pero que, por un lado, también suponen un intento por apuntalar las coordenadas de una escritura en el seno de la modernidad y, por otro, por fijar la peculiar óptica de cada autor acerca de todos estos estímulos culturales, tomando en cuenta -y esto es lo más relevante- su particular relación con el lenguaje poético. Como intentaremos demostrar, en Íntimo ser la óptica individual de su autor amalgama todos estos estímulos de una manera muy personal, algo que está inherentemente relacionado con el propio carácter de su creador que, en palabras de Sabas Martín (1993, p. 15):

[...] era anárquico en cuanto a método y procedimiento de escritura. Escribía, guardaba, perdía, encontraba... Corregía poco, dando casi por definitivas las primeras redacciones de sus poemas, procurando así que se mantuviese viva y fluida la estructura onírica, visionaria y envolvente de su poesía. Más sentimental que intelectual, esa constante de su obra fue también una característica de su actitud ante la vida.

\section{EN LOS ENTRESIJOS DEL PROCESO DE ESCRITURA DE ÍNTIMO SER}

Podemos considerar Íntimo ser como un libro aluvional, donde se albergan poemas anteriores a 1936, algunos de los cuales ya estaban escritos desde 1928 bajo la influencia de su hermano y mentor Julio de la Rosa ${ }^{1}$. En este libro encontramos poemas con presencia del verso medido y breve que conviven con otras composiciones ligadas a una orientación surrealista aún incipiente. Así, pues, esta plaquette es una antesala de lo que será toda la poesía posterior del poeta, lo que señala, ya desde un principio, que las coordenadas creativas de toda la obra de José de la Rosa apuntan a una influencia in crescendo de la estética surrealista.

Desde este primer poemario, su poesía es poesía de encuentros: la mirada construye valores latentes que el tiempo pone en las cosas, en los hechos, en aquello que está encadenado al devenir cronológico. La mirada descompone lo que toca -de ahí la importancia de la percepción sensorial en nuestro poeta-, como forma de fusión con y en todo; por eso cobrará capital protagonismo el impulso erótico. A través de elementos reales como estos se desliza la emoción, desplazamiento posible gracias al fuerte simbolismo que despiertan en el poeta. Todo pierde consistencia, se vuelve "íntimo ser", pues la realidad esencial está anclada en el movimiento; de ahí el gran valor de lo pictórico como medio de fijar este devenir elemental. Todo se 
vuelve flexible, manejable: es un ensayo por sostener el cambio. De aquí nace el pulso entre esta percepción y los archivos del poeta, y se torna todo ello en poesía de flujos metafóricos, de búsquedas constantes, de dureza velocísima. Sobresale la vaguedad en la lectura, muy connotativa, vaguedad también en la mirada que, contradictoriamente, nos sumerge más en la sombra, un espacio vital desde el que afrontar la escritura y que es clave para interpretar este libro primero.

Como muestra del gusto por las formas breves que esbozamos más arriba tenemos los poemas I, IV, VI, IX y X, que probablemente se encuentran entre los inicialmente escritos por el poeta ${ }^{2}$. En el primer poema del poemario, lo fugitivo, en forma de aire, humo y claridades es el punto de relación para recordar a los que se fueron. El carácter biográfico y vital queda, así, distinguido:

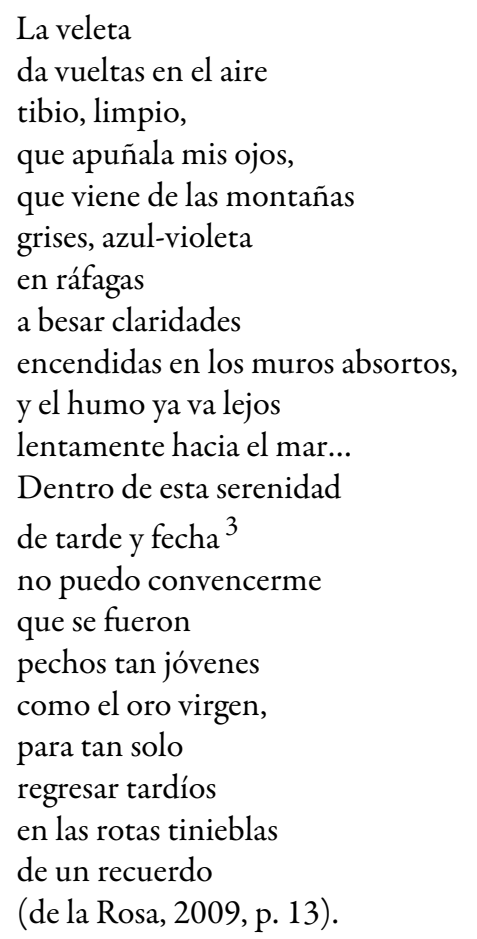

Hemos de recordar una vez más que dos jóvenes poetas, Julio de la Rosa, su hermano, y José Antonio Rojas, amigo del poeta y de su hermano Julio, fallecieron la noche del 20 de agosto de 1930 en el muelle de Santa Cruz de Tenerife, al caerse al mar cuando iban en barca. Este es el recuerdo que atenaza la mente de José de la Rosa, metafóricamente esa "veleta" que recoge y transforma los recuerdos, siendo sintomático que metonímicamente se refiera a esos dos poetas como "pechos tan jóvenes". El aire es, como la palabra, una forma metamórfica del recuerdo y del paso de la vida, pero es "aire / tibio, limpio", dos adjetivos que encajan en la misma raíz de la idea de recordar: por un lado, la cercanía, la amistad entre el poeta y los "pechos" que trae a la memoria ${ }^{4}$ y, por otro, el carácter del aire, "limpio", en clara alusión al cariz de su propia palabra limpia, nueva, dos vocablos muy ligados a la primera vanguardia insular.

Uno de los rasgos de los primeros poetas de la vanguardia en Canarias es el manejo de los signos de puntuación con un valor más allá del que tienen habitualmente, como puede apreciarse en algunos de los textos primeros de Gerardo Diego -pensemos, por ejemplo, en Manual de espumas (1924). Los puntos suspensivos aparecen en el cuarto viraje poético de este libro como marcas de una estructura abierta que dejan el poema, al igual que ocurre con la puerta, "entornado", como un fragmento de luz, de pensamiento. La ausencia de proposiciones principales acentúa ese carácter fragmentario, al mismo tiempo que deja los versos como si fueran palabras dichas en voz alta:

...Y en la entornada puerta

-dormido-. 


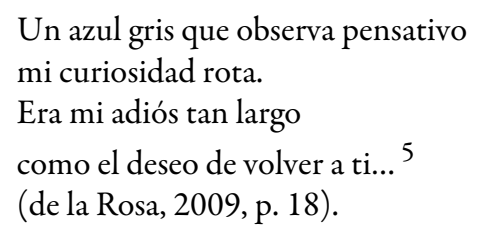

En consecuencia, y dada su levedad, el poema se queda como un impulso apenas iniciado cuyo valor es intransitivo. Es un esfuerzo que no llega a ninguna parte. El agua simboliza en el poema VI esa imposibilidad; este equivalente líquido de la luz se torna impenetrable ("agua de metal"), con lo que se relaciona con la tierra y se niega su movimiento. Más que agua, es un reflejo del agua, reflejo que, textualmente, aparece al final del poema en forma de eco, de reiteración que no lleva a ningún lado. En esta breve composición, las estructuras "sustantivo + preposición + sustantivo" fijan, como el agua, las imágenes como inertes reflejos o detenidos fervores:

$$
\begin{aligned}
& \text { Agua de metal } \\
& \text { ¿por qué me miras? } \\
& \text { si no puedo contarte } \\
& \text { lo que ella me ocultó } \\
& \text { en sus labios secos. } \\
& \text { Agua de metal } \\
& \text { ¿por qué me miras... }{ }^{6} \\
& \text { (de la Rosa, 2009, p. 20). }
\end{aligned}
$$

Y es ese fervor metafórico el que ha enarbolado a la joven generación de la vanguardia insular. Como en los versos anteriores, en IX el lector intuye que se pasa de la tarde a la noche a través del dinamismo metafórico, a lo que hay que añadir la pericia pictórica del poeta, que es la que envuelve, en su valor durativo, la llegada de la oscuridad. Es altamente sugerente cómo este poema empieza con una comparación de la que solo se nos muestra el segundo término, lo que ya desde un principio aniquila la barrera realidad-sueño:

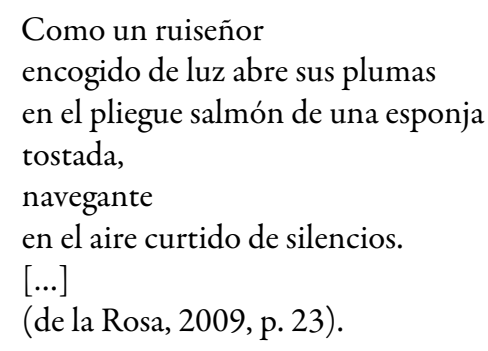

La quietud aviva el fulgor metafórico de lo que presagia, como el "gorrión”, símbolo tradicional de buenos augurios enaltecidos por su habilidad cantora:

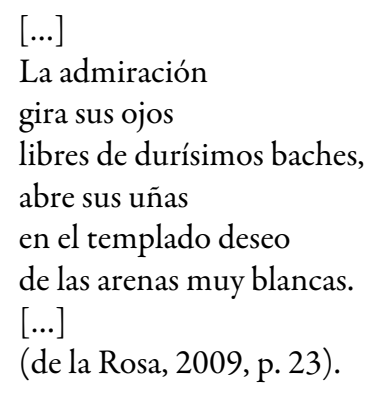

Este buen augurio hace que el propio momento del día -el sol como vértice de sus propios rayos- se convierta en signo de admiración, de sorpresa, pues se encumbra la luz al estar el “aire curtido de silencios”. De este modo, el carácter pictórico - podríamos hablar, incluso, de perifrasis pictórica- de esta estampa poética resalta aún más; esta brillantez en el uso de la imagen nos recuerda a los poemas de Diario de un sol de verano, 
de su amigo Domingo López Torres, llenos de contrastes lumínicos, aunque el sentido más lúdico del autor de Lo imprevisto no aparece en José de la Rosa. Ese sentido visual de la poética de la primera vanguardia se observa con claridad en el orden de los propios elementos poéticos de los últimos versos:

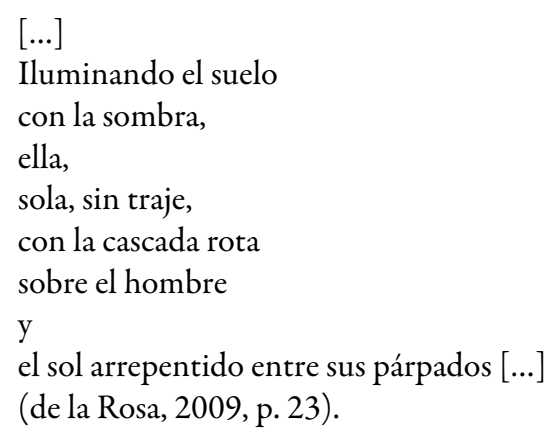

"Iluminando" y "sombra" son vocablos antónimos, cuyo valor no solo queda resaltado por la posición en el verso, sino por el hecho de pertenecer a categorías gramaticales distintas: se ve esa irreal iluminación de la sombra como proceso en su duración, sin principio ni fin. Además, junto a recursos como este encontramos otros que apuntan a nuestro sentido de la vista, donde escritura del verso y sentido se dan la mano; así, la palabra "ella", en efecto, aparece sola, como apostilla el verso siguiente. Este pronombre personal puede aludir a la luna, símbolo romántico por antonomasia de la soledad que, a su vez, apostilla la propia soledad del poeta.

En otros poemas, que parecen navegar en la órbita creacionista en la que bucearon otras voces de la lírica insular ${ }^{7}$, la ausencia de puntuación hace tomar al lector un papel decisivo en la interpretación y en la lectura del poema. Se produce, de este modo, una perseguida mezcla de significados con la finalidad de eliminar el muro entre el elemento real, generalmente emanado del paisaje, y el elemento irreal o poético, de lo cual resulta la creación de una realidad nueva. El poeta busca la expresión de su propia situación en cualquier realidad -especialmente en la geografía insular, geografía de ecos y soledades-, como en Vicente Aleixandre, con un valor simbólico; lo arbitrario, si aparece, es tan solo aparente. Así, al menos, interpretamos nosotros el poema $\mathrm{X}$ :

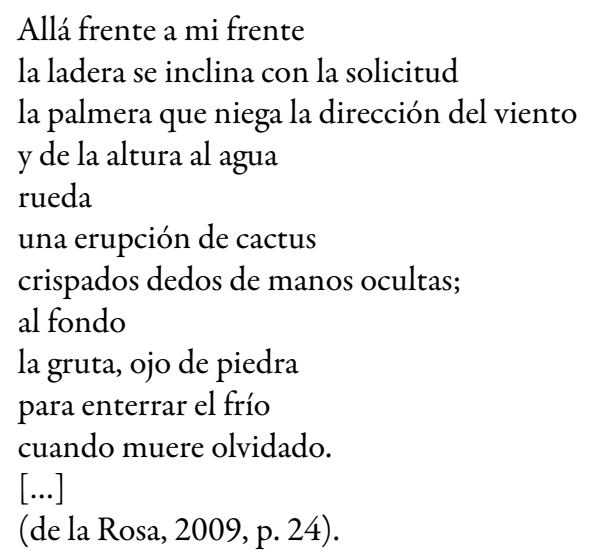

Con esta ausencia de puntuación -solo un punto y coma que, de forma deliberada, separa lo visto del punto de referencia desde el que se mira- la palabra es más que palabra: es objeto, trazo en el cuadro, elemento resonador ${ }^{8}$. La lógica cede paso a mundos imaginarios, vistos desde dentro, "al fondo / la gruta, ojo de piedra”, espacio que queda solidificado, sin trajes, esquematizado, al ser un espacio psicológico. El ritmo de la conciencia dibuja, así, paisajes imprevistos, alejados de los que el sujeto controla habitualmente por su conocimiento del entorno. Lo imprevisto no solo sorprende: revela.

La órbita creacionista pensamos que vuelve a ser el marco ideal para la interpretación del poema VIII, donde el motivo de las tenazas, que ayudan a forjar los metales, símbolos de lo consistente, puede entenderse 
como impulso del que germina la propia actividad poética por esa idea de dominio, de aprensión, de dar forma; esta composición, además, se podría relacionar con la técnica surrealista del "objeto encontrado", que genera múltiples asociaciones puramente poéticas. El objeto poético sufre una mutabilidad constante:

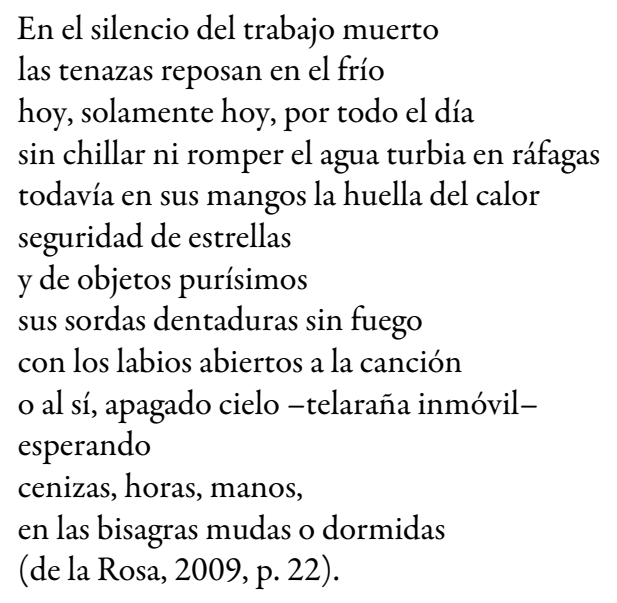

Aunque esta será una idea sobre la que volvamos en más de una ocasión, de la Rosa siempre tiene la ambición de situar en un espacio no físico sino existencial determinadas realidades de alto valor simbólico. Es por ello por lo que preposiciones como "en" o "entre" serán muy abundantes al principio del poema, lo que, por su posición, les concede un valor preeminente. En este caso, el lugar escogido es el silencio, por su gran valor connotativo.

Según Cooper (2000, p. 173), las tenazas, junto al martillo y el yunque "son atributo de los dioses herreros", lo que puede ser -algo que no es nada extraño en de la Rosa- una referencia metapoética de la propia actividad creadora. Así, el poema es un cuadro poético donde un objeto cotidiano es sublimado, rasgo este muy caro a los poetas insulares de mediados y finales de los años veinte. El hecho de que en este poema todo se manifieste en la más absoluta quietud y silencio nos indica que es la noche el momento elegido, aquel en el que la labor diaria del hombre cesa y en el que la actividad taumatúrgica se acrecienta; no en vano, la referencia a la “telaraña inmóvil”, altamente simbólica, junto a la idea de tejer, siempre asociada desde la época clásica a la creación, puede tener el valor de metáfora cósmica, trasunto del universo. Pero, más allá de estas hipótesis, la noche, como el objeto elegido, es, más que un momento, una instancia para la evocación. Este poema sería una evocación en voz alta, una recreación lírica, aquella de la que tanto gustaban en sus inicios poetas como Pedro García Cabrera, Emeterio Gutiérrez Albelo, o Domingo López Torres.

En este mismo ámbito creativo de la primera vanguardia pensamos que se generó el poema III, que comparte con el anterior ciertos rasgos que podríamos denominar "barrocos", fundamentados en la voluntad de emplear recursos conceptuales; así, en el poema anterior teníamos la antanaclasis ("frente a mi frente") o el hipérbaton ("crispados dedos de manos ocultas"), mientras en este aparece la antítesis ("murió naciendo" o "me renovó su adiós de siempre juntos"), la contradicción lógica, racional, que solo puede ser rota por un "capricho", algo arbitrario que, simplemente, se produce, surge sin más para hundirse en las fauces del olvido:

Brisas muy hondas, al cerebro fijan

mendigos de dolor-labios ausentes...

Mi capricho encendido

fue leve,

solo,

blanco,

quedó sin fuerzas, dormido en una estrella,

aunque quiso romper los calendarios

empujando los siglos hacia atrás

murió naciendo,

se marchó de día prendido en un brocal de agua muy clara 
vacilante, indeciso,

me renovó su adiós de siempre juntos

(de la Rosa, 2009, p. 17).

La pureza de ese recuerdo -fugaz como la luz, alto como una estrella- es lo único que se salva. El agua relaciona la idea de reflejo, elemento que fluye y busca su cauce, con el recuerdo para poder renovarse. El simbolismo del pozo ("brocal de agua muy clara") es muy alto: en contacto con el mundo subterráneo sus aguas mágicas pueden satisfacer cualquier deseo; también puede ser símbolo, incluso, del alma. El acto de recordar es como el peregrino: se va para volver nuevamente, con los ánimos renovados. Nótese cómo ese ir y venir del ejercicio de la memoria ("brisas") hace caer al poeta en la mayor de las miserias y de las pobrezas.

A pesar de todo lo que hemos comentado hasta aquí, en Íntimo ser se inician los latidos poéticos de la estética surrealista en nuestro poeta, pues son los que mejor se acomodan a su talante vital. El poeta ofrece enérgicas pulsiones como forma de liberar fuerzas ocultas, que se expanden, como río desbordado, a borbotones, de forma tumultuosa, y que ensanchan los caminos de la expresión poética. Composiciones como esta enfatizan nuestra idea de su condición visionaria, la importancia de la experiencia íntima, que hace que el lenguaje se alce sobre sus propios límites semántico-sintáctico-simbólicos: parece como si la estética actitud ante el arte y la vida- surrealista aboliese los límites de la inteligencia y, por tanto, del lenguaje poético convencional para enaltecer el protagonismo de la intuición, que fluye por los rincones más recónditos del ser, como sangre que corre a gritos. Por ello, el surrealismo es puerta de escape de una psicología atormentada, dado que el lenguaje surrealista puede recoger lo imprevisible ${ }^{9}$.

Este es el caso del poema II, donde José de la Rosa construye todo un cosmos existencial determinado por la dureza y la sensación de calor que agobia y oprime su vida. Las continuas referencias al paisaje quemado o a las cenizas señalan la presencia de la muerte:

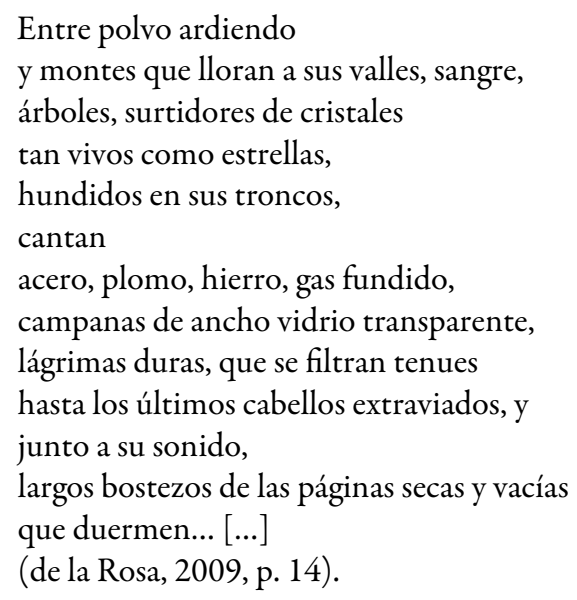

El engranaje metafórico de este inicio es enormemente críptico. Se produce una fusión de estados partiendo de la disolución del mundo terrenal que representa el "polvo", estado de máxima destrucción aún perceptible según Juan Eduardo Cirlot (1998, p. 375), donde las distancias entre lo grande y lo pequeño ceden paso a una suerte de diálogo entre el mundo infernal o subterráneo, con las referencias a los metales ("acero, plomo, hierro”) y el mundo de superficie, siendo el árbol, que representa la vida, el elemento de unión entre lo infernal, lo terrenal y lo celeste. La propia estructura versal de este principio del poema, marcada por los continuos hipérbatos, refleja esa noción de continua metamorfosis, donde destrucción y regeneración van de la mano y no se sabe muy bien qué elemento de los dos es el más conveniente, pues parece que es el propio proceso el que más agrada al poeta, al ser el que se aferra mejor a su propia situación por ser un paisaje de muerte - con sus oscuros cromatismos- el que se dibuja. El entramado simbólico de formas y texturas ayuda al poeta a desarrollar este panorama desolador; de este modo, el árbol en llamas puede ser un "surtidor de cristales" y su tronco hueco se convierte en "campana de ancho vidrio transparente", con lo que el fuego, 
elemento destructor y a la vez purificador, es el verdadero protagonista. El fuego funde, iguala, convierte lo heteróclito en unidad, lo que hace prevalecer su valor poético esencial. El rojo - "sangre"- lo invade todo a la vez que todo lo confunde y lo equipara. Este paisaje disoluto une contrarios y hace que incluso lo sórdido adquiera rango poético:

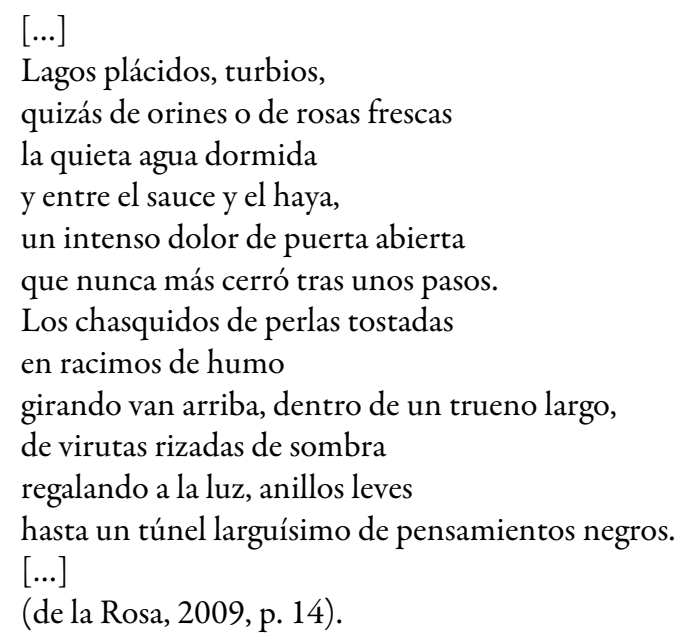

En esta tormenta poética, que nos trae a la mente los cuadros La jirafa en llamas (1936), de Salvador Dalí o, también, el de René Magritte titulado La duración apuñalada (1938), con la imagen de una locomotora atravesando la chimenea de una casa, llama la atención la presencia de los elementos abiertos o que representan el vacío, cuna de la desesperanza, de lo sórdido y negro y, también, de la pesadumbre existencial del poeta. El magma conceptual del texto es como el agua que fluye cual torrente, desde lo superficial y exterior hasta lo subterráneo e íntimo, del día a la noche, de lo plácido a lo turbio, del fuego a la ceniza.

El grado de fijación se aprecia en la ausencia de acción por la falta de verbos en forma personal; sin embargo, el movimiento conceptual se logra gracias a la dialéctica que se establece entre términos antagónicos que producen una fuerte tensión. Así, por ejemplo, el agua del lago nos coloca en el camino de lo escondido y misterioso, siendo otra puerta que conecta lo superficial con lo profundo; por su parte, ese intenso dolor de "puerta abierta" puede ser una referencia intratextual que justifique, en cierta medida, el paso de un mundo a otro. Esta aparente naturalidad está en la base del surrealismo.

Tras el fuego, la tierra y el agua solo queda el humo, que según Cirlot (1998, p. 253) “es un símbolo del eje valle-montaña”, elemento que encajaría dentro del planteamiento simbólico que avistamos al principio del poema. No hemos de olvidar que el humo también es una forma de escape, de huida, a la vez que a lo largo de toda la literatura española se ha identificado con la brevedad y el tránsito hacia otra realidad. En todo caso, todas estas hipótesis interpretativas caben aquí.

Imágenes de gran calado emocional como las de "sueños metálicos", "profundos ojos de llamas sincrónicas", "reloj amarillo de audaz muerte", "ángeles agobiados por un peso de sangre" 10 o "romper11 los corazones de asfalto o roca viva" son muestras dramáticas de un paisaje cíclico que corona la vida de los hombres, paisaje febril sin esperanza, lleno de soledad, silencio y sombras, donde el instinto ${ }^{12}$ está siempre latente:

$[\ldots]$

Abarrotada de signos vacíos,

sin lágrimas ni paz, con la fe hendida

ronda la triste tierra

de hombres abandonados a huesos perdidos

los Siglos

(de la Rosa, 2009, p. 16). 
Este poema, uno de los más extensos es, también, un buen modelo de poema largo, tan del gusto surrealista. Responde, en este sentido, a la idea de variedad en la unidad; más que inicio, desarrollo y fin, en José de la Rosa sus poemas más largos son puro desarrollo, que se centra en lo sorpresivo del imaginario que cada intensa unión de vocablos genera. Podríamos afirmar, con Octavio Paz (1990, p. 27), que "el poema extenso se vuelve una sucesión de momentos intensos".

Poemas de penumbra como este son los que, a nuestro juicio, otorgan merecidamente a nuestro poeta la calificación de surrealista que algunos críticos le conceden, como es el caso de Andrés Sánchez Robayna (1989, p. 29):

Más allá de los contagios o las "adherencias" de tal o cual aspecto del ideario bretoniano -visibles aquí y allí en muy diferentes escritores-, puede decirse que los autores canarios del período prebélico en cuyas obras se advierte una plena conciencia de ese ideario y una adopción inequívoca de la poética surrealista (siquiera episódica) son los siguientes: Agustín Espinosa (1897-1939), Emeterio Gutiérrez Albelo (1905-1969), Pedro García Cabrera (1905-1981), José María de la Rosa (1908- ), Ramón Feria (1909-1942) y Domingo López Torres (1910-1937). El grado de adopción del surrealismo es desigual y variable en cada uno de ellos, pero la pureza respecto al "programa sin programa" francés es, en general, una nota característica en buena parte de los textos (poesía, prosa, narrativa, ensayo, teatro) ${ }^{13}$.

Esta capacidad imaginativa, en múltiples ocasiones de claro simbolismo negativo, la apreciamos también en el poema $\mathrm{V}$, que transcribimos a continuación:

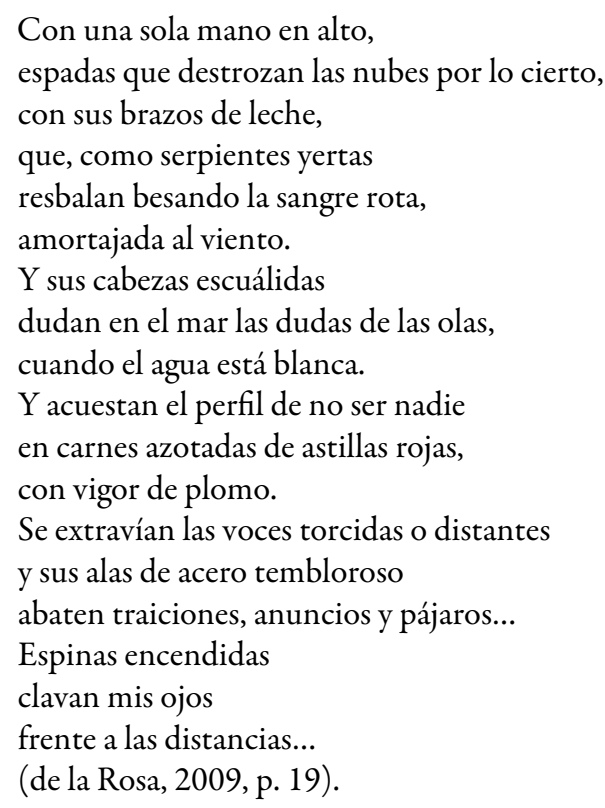

La aparición de elementos cortantes que hieren ("espadas", "astillas", “espinas”), signos del dolor, junto con la presencia de ciertos elementos inquietantes relacionados con la muerte ("serpiente", "sangre") intensifican ese simbolismo negativo del que más arriba hablábamos, algo que se ve agrandado por el empleo de la comparación, que vincula lo real con lo irreal ${ }^{14}$, la vigilia con el sueño, aspecto este que es recurrente en José de la Rosa y en la poética surrealista. Ante esto el yo poético es un espectador pasivo, pues de él no depende la orientación de la mirada, clavada por "espinas encendidas", imagen de claras resonancias bíblicas, pues no tiene ni tan siquiera el dominio de sí mismo, lo que se relaciona, también, con la desintegración de la identidad, pues en el poema solo aparecen miembros concretos de la anatomía humana ("mano", "cabezas", "ojos"), justamente aquellas partes corporales que se vinculan tradicionalmente con la hegemonía y el poder del ser humano. Ahora las facultades de estas partes del cuerpo se asocian al sufrimiento, a lo que ayuda la propia adjetivación que, no lo olvidemos, José de la Rosa empleará recurrentemente con una consideración negativa. 
Otro aspecto frecuente en José de la Rosa es la aparición de elementos de carácter sólido, que niegan vitalidad, como hemos señalado, también, en el poema II. Esta es, a nuestro juicio otra forma de tildar los estados anímicos y presentarlos como realidad dura e insondable lo que, a su vez, es una forma de objetivarlos y alejarlos del ser humano al darles autonomía. Así, vemos que la capacidad analítica de nuestro poeta siempre encuentra sitio en su poesía, pues es una parte trascendental de la misma, ver una fuerte dependencia de esta serie de estados de solidez. El impactante imaginario de algunos de estos poemas no deja lugar a dudas de la importancia del surrealismo en este poeta; pensamos, por ejemplo, que muchas veces la abstracción del espacio, visto como totalidad, hace que determinadas referencias del paisaje se conviertan, también, en formas del espacio gracias a su conversión en realidades sólidas, que se pueden ver y que nos recuerdan los paisajes petrificados de Yves Tanguy o, también, a algunos cuadros de la pintora checa Toyen. De esta manera, tenemos el caso de "resbalan besando la sangre rota, / amortajada al viento", para solidificar el crepúsculo, o bien la alusión a los rayos solares como "astillas rojas, / con vigor de plomo" (de la Rosa, 2009, p. 19). El propio devenir de la realidad solar creemos que expresa bien lo que el poeta persigue: los ojos retienen perfiles de una realidad que trata de fijar idiomáticamente, pero lo que queda es un inquietante y tétrico cuadro de claroscuros. El final abierto genera en el lector las mismas dudas que tiene el poeta.

Partiendo del comentario del poema anterior, no puede resultar extraño que podamos hablar de una búsqueda y asentamiento en la forma para signar la poesía del hermano de Julio Antonio de la Rosa. Vamos observando cómo hay un ferviente deseo por dar forma o, por decirlo de otra manera, convertir en recipiente lo que son estados intangibles para, de este modo, apresar lo efímero, lo pasajero, lo que será bastante habitual en él. Metafóricamente, pensamos que las realidades leves por su transitoriedad son como astillas que hieren la retina del poeta. Buen ejemplo de ello es el poema VII en el que la propia ambigüedad cromática desvela este gusto por aprehender las cosas a medida que resbalan por el tiempo y en el que el motivo de "las nubes" nos recuerda a los cuadros de Magritte:

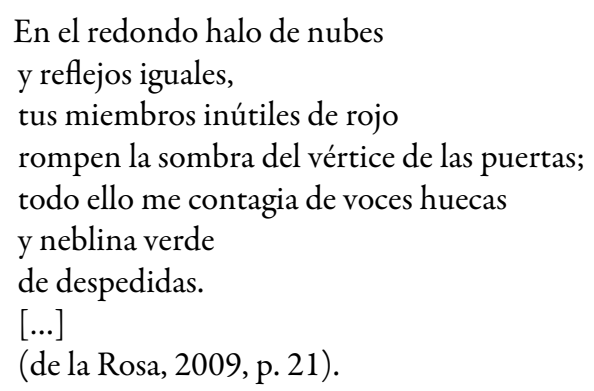

El rojo, color de las emociones, de los esfuerzos, de los impulsos, es el término proposicional de unos "miembros inútiles", nomenclatura corporal de un "tú" o destinatario que no aparece. Solo sabemos que estos están situados en lo alto evanescente, pudiendo ser, de este modo, una personificación de la luz celeste en el crepúsculo, cuya tonalidad se va haciendo cada vez más intensa. Ese momento, donde el "halo de nubes" es augurio de algo que va a suceder, es el escogido por el poeta para abrir su mundo interior y para abrirse al mundo. Las menciones a entidades que muestran la idea de imprecisión ("halo de nubes", "reflejos iguales", "neblina verde") creemos que hace hincapié en esta unión identificativa. La luz crepuscular recubre de vaguedades el paisaje; es el instante en el que el poeta forja su imagen sobrecogedora. "El martillo" y "los hierros" encarnan el suplicio y la severidad de esta construcción. La imagen -reflejo- se hunde en el espacio ocular y despierta "los archivos" - dormidos- de la memoria:

$[\ldots]$

El vapor aeronauta y las chispas curiosas

entre el sonido de los hierros

en que existe el destino

sin despertar al martillo desnudo

que en el espejo de una visera 


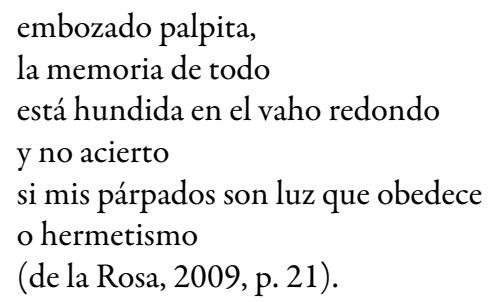

Luz y sombra comparten lo mismo. Esa "o" final, como en Vicente Aleixandre, es un nexo coordinante que no presenta dos opciones, sino que identifica los elementos que une: ambos revelan, siendo los lados que convergen en el vértice de la creación poética de José de la Rosa. Por ello menciona el “vaho redondo”, pues la imprecisión todo lo contiene, es el recipiente de la verdad. Esta creencia desaforada en lo ambiguo, en las claras sombras y en las luces cegadoras como principio creativo será un verdadero eje vertebral en toda su obra lírica.

El mar o, más bien, la visión trágica de este es un tema obsesivo también en toda su poesía. La existencia humana se ha identificado desde la más remota antigüedad con la navegación; si a esto le añadimos lo íntimamente relacionado que está este motivo con las visiones de 'transportar', 'aventura' o 'explorar', tenemos ya un amplio abanico de resonancias que fácilmente encajan en la particular forma de mirar de nuestro poeta. El poema XI va en esta dirección:

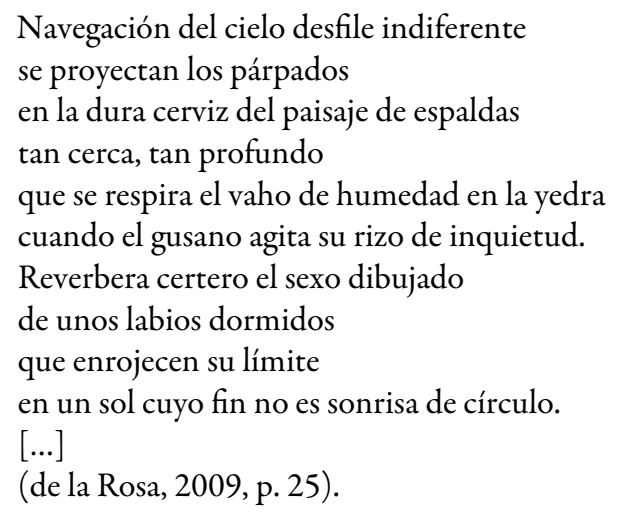

Nuevamente, los sintagmas se unen haciendo más densa la neblina poética. Se produce una inversión del verdadero valor del sustantivo "navegación", que ahora se proyecta no en el agua, sino en el cielo, aunque es una navegación -un desfile, con lo que tiene este término de convencionalismo- sintomáticamente "indiferente", porque la idea que late en el primer verso de la composición es la de 'velocidad' irrefrenable de la conciencia. El poeta mira hacia arriba y, cegado por la luz, cansado por la monotonía de ese espectáculo ("desfile"), sus ojos se cierran, acto metonímicamente representado en la idea de que "se proyectan los párpados", y el paisaje se vuelve "de espaldas", es decir, se da una visión del mismo en lo profundo de la conciencia del poeta; por eso se sitúa "tan cerca, tan profundo", precipicio que nos trae a la mente, también, la hondura telúrica, al ser un espacio primario, donde predominan el instinto y lo inconsciente. Así, pues, en este inicio el poeta hace asociaciones emotivas ${ }^{15}$ entre los distintos enunciados poéticos, con lo que el poema se convierte en un corpus visionario, lleno de latencias profundamente humanas.

Líneas más arriba nos deteníamos en la velocidad con la que se suceden las imágenes. En múltiples ocasiones, al juntar esta idea con la de recordar ("Reverbera certero el sexo dibujado" [de la Rosa, 2009, p. 25]) o con ciertos tintes eróticos, la idea de vacío, de espacio lleno de ilimitadas distancias se agiganta. Este paisaje no es verdadero para el poeta y por ello debe acudir a la definición negativa: "en un sol cuyo fin no es sonrisa de círculo" (de la Rosa, 2009, p. 25). Los signos del amor y la pasión, de la alegría vital ("sexo dibujado", "labios dormidos") no son más que falacias. Ciertamente, en algunos momentos hay huellas en la dicción de José de la Rosa que nos recuerdan al mejor Jorge Guillén: 


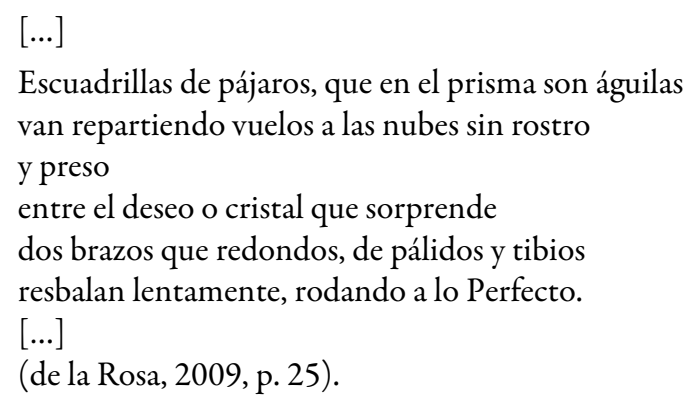

El vuelo de los pájaros ${ }^{16}$, símbolo de lo trascendente que, en su reflejo, converge en la unidad, está representado por el águila; lo diverso se hace unitario en la conciencia, y todo ello "entre el deseo o cristal que sorprende" hace ver que estamos ante un poema visionario, ante un acto de ensoñación ${ }^{17}$, un panorama emocional onírico que persigue lo redondo ("rodando a lo Perfecto"), con mayúsculas, pues representa lo absoluto, una imposibilidad. Esta es la gran contradicción del poeta: enfrentar el vacío de la realidad le hace refugiarse en sus recuerdos y ensoñaciones y, contradictoriamente, ahí es donde descubre el gran vacío de la existencia, la intransitividad de sus actos. En este ámbito de cosas se sitúa la imposibilidad del acto sexual, en este caso reflejada en la intransitividad de la masturbación:

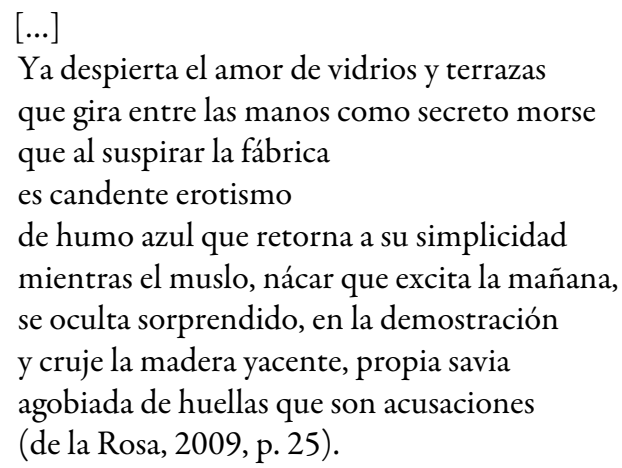

Y es que todo es creación: las múltiples referencias a elementos relacionados con la imagen como los ojos, el cristal, los vidrios o las manos son referencias metonímicas al vacío que late tras lo creado. Por eso a nuestro poeta le interesa captar la esencia de sí mismo y de su realidad en movimiento, pues todo lo pasado, al retornar a la conciencia, es un sueño que no esconde más que las huellas del vacío, una forma, no lo olvidemos, de la inexistencia.

Esta sordidez existencial en la que son tan reincidentes formas conceptuales de la ausencia como las huellas, la imagen o los ecos, nos hace ver que para José de la Rosa el presente de la vida cotidiana no fundamenta su vida. Hay una renuncia consciente a vivir hacia afuera, hacia lo que está pasando, para refugiarse en "un tiempo discurrido", signado por "un raro silencio de pergamino y polvo". En la nocturnidad el poeta anda perdido entre "viejos cristales", que lo comunican con una verdad amarga y cruel; ciertamente los tintes biográficos en algunos poemas, como el XII, parecen difíciles de refutar. Esta contradicción entre lo de fuera -inerte y frío- y lo de dentro -el fuego, la vida que le transmite el pasado más reciente, lo auténtico y verdadero- es la que se respira en estos versos:

Este fuego, que derrite mis sienes fatigadas quizás luz, que de lejos, viene a mis ojos pura en azul melancólico de un breve trapo inerte, forjado de marfil rosas inusitadas de abiertísimos pétalos,

que flotando en mis venas, como dolor de espuma deshace la distancia, mordiendo sus latidos, que vive, en los músculos de hielo ronco y torpe.

Mientras, 


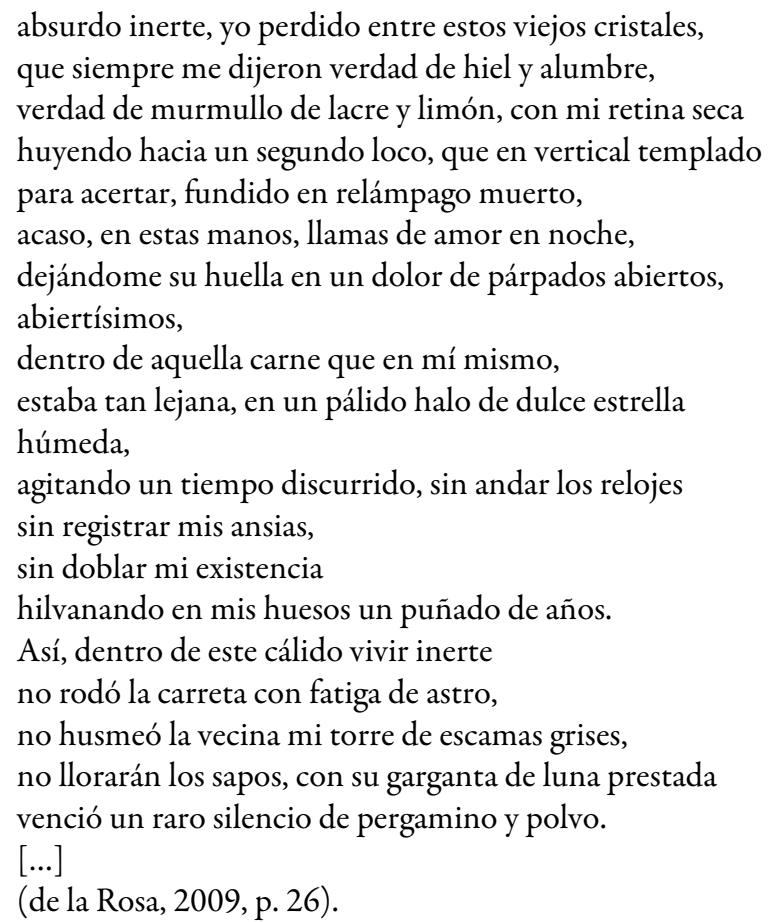

Las continuas tensiones se reflejan al principio: el fuego, la luz, las rosas son símbolos de estados interiores, que chocan con elementos del mundo exterior, como "trapo inerte", "marfil", "músculos de hielo ronco y torpe". Esa tensión es la lucha por hacer visible, en la escritura, ese desvivirse íntimo. Esta tensión es llevada a sus últimos extremos gracias, también, al empleo del verso largo, cauce de todo ese magma emocional que permite la utilización de símbolos de amplio valor sintético-conceptual, que se manifiestan como un ejemplo más de desesperación y frustración ante la ensoñación de un duro pasado; así, la palabra se libera y aparece plena, como posibilidad semántica -y vital- infinita. Este es otro ejemplo más, pues, de la libertad surrealista.

Y es que el yo se encuentra perdido como observador de su entorno; de ahí que sea muy relevante la idea de estar enclaustrado en el interior de una habitación, una relevancia, para nosotros, doble: de un lado, simboliza la imposibilidad de sacar esos estados ígneos de su espíritu hacia fuera; de otro, la escasa relevancia que tiene el mundo exterior frente a la torrencial fuerza de su océano anímico. De tal forma, no nos puede resultar extraño que la mirada hacia el exterior, del mismo modo que el intento por materializar a través de la pluma la interioridad, tenga como inerte respuesta sintagmas del tipo "mi retina seca", "relámpago muerto" o "dolor de párpados abiertos". Esa contradicción vital dentro-fuera tiene su traducción poética en el verso "así, dentro de este cálido vivir inerte", definición casi sepulcral a la que le sigue una serie de eslabones negativos -donde la anáfora hace las veces de martillo que golpea sobre el yunque de la conciencia-, fácilmente relacionables con la ausencia de la claridad solar o de la luz del día o, lo que es lo mismo, una vida llena de sombras y silencios, el ámbito protector que supone su propia interioridad, metonímicamente apreciable en las "escamas grises" y, por último, la soledad, "personificada" en el canto que el sapo dedica cada noche a la luna ${ }^{18}$. En composiciones como esta podemos apreciar que hay enigmáticos y secretos desplazamientos de una imagen a otra; una suerte de continuidad emocional las hilvana a través de la yuxtaposición que pone al mismo nivel lo unido. A veces, un sintagma, un motivo, es el generador de estas yuxtaposiciones, como es aquí el caso de "este fuego".

No hay duda, como ya hemos apuntado con anterioridad, de que la muerte de su hermano fue un durísimo revés en la vida de nuestro poeta. La trágica ausencia de su primer amigo y maestro dejó su voz -y su vidalacerada para siempre. El poema XIII escrito, probablemente, después del trágico suceso que hemos relatado más arriba, es la prueba de esa "fija circunstancia” -la angustia por la pérdida y la forma en que se produjoque enmaraña de tintes lóbregos la mayor parte de los textos de Íntimo ser. En muchas ocasiones, el poeta encuentra en la infancia la fe y la inocencia que el mundo en que vive le niega. Este es el poema: 


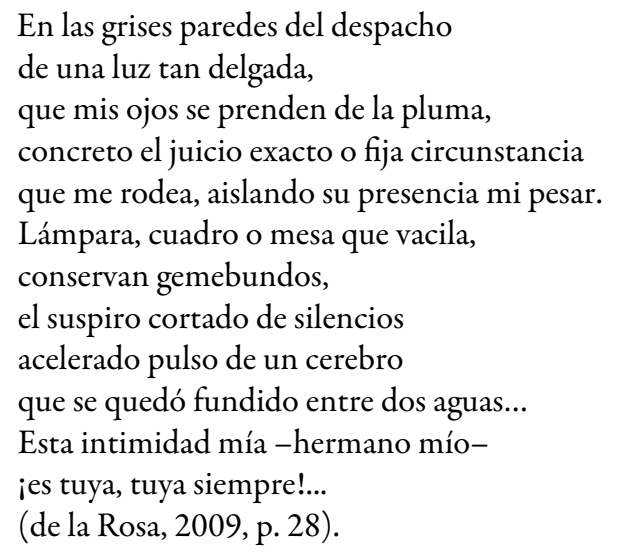

Este poema se convierte en toda una declaración de intenciones. José de la Rosa establece aquí como pauta principal de su escritura que esta gran ausencia es y será "el juicio exacto o fija circunstancia / que me rodea, aislando su presencia mi pesar”. El hipérbaton final traduce bien esa separación irreparable que supone la muerte de un ser querido, quedando distinguido el motivo central al quedar a final de verso, ese "pesar" que palpita en cada verso de cada poema. El propio entorno de la habitación, ámbito íntimo, esconde resonancias de los diálogos entre los hermanos, lo que, metafóricamente, hace que el poeta encierre en la expresión popular "fundido entre dos aguas" el estado anímico extremo en que se encuentra al ser recobrados aquellos por su memoria. Ese silencio queda señalado por los puntos suspensivos que, como el aliento del escribiente, quedan levitando en el aire.

En este poemario en el que de la Rosa acopla su torrencial poético primero hay una obsesiva presencia del color azul, que para nuestro poeta tiene notables tintes biográficos. Este cariz es la que se aprecia en el poema $\mathrm{XIV}$, en la que el mar, siempre "el mismo y tan distinto", es emblema de la soledad que el propio poeta padece y que la tarde, con sus connotaciones tan machadianas, acrecienta:

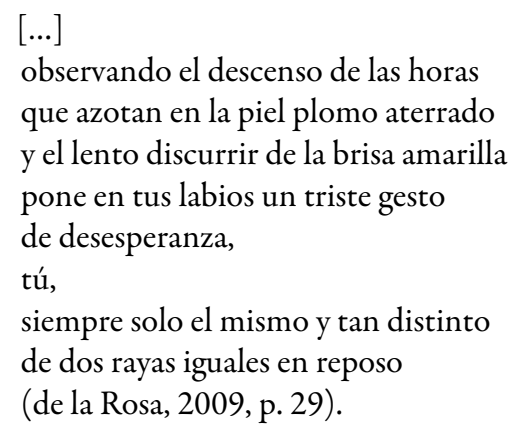

Si hay un elemento ya prefigurado en Íntimo ser que se convertirá en una constante en poemarios posteriores es la sensación de opresión que siente el poeta en su interior. La tensión que esta situación produce encuentra en el poema XV cauce lírico en la visión que el poeta tiene de sí mismo como recipiente: lo redondo es signo de lo vacío, pero también del eco, resonancia que acrecienta motivos como la soledad y el propio vacío interior. Así, los escalofríos y temores más personales se expresarán por una dialéctica de lo redondo, que encontrará en Vértice..., su mejor poemario, una expresión más acabada. El ejemplo del que hablamos es el siguiente:

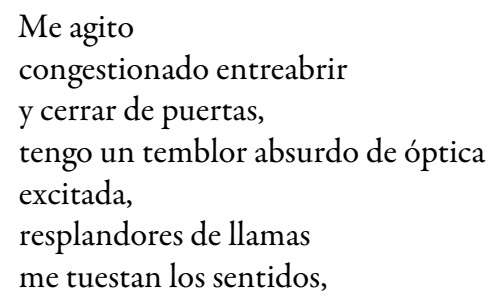




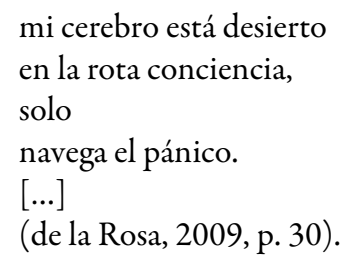

Otro de los valores connotativos que lo redondo sugiere es el de su relación con lo irracional, con lo absurdo, término este que aparece en el cuarto verso del poema ("tengo un temblor absurdo de óptica"). El empleo de este vocablo ya carga las tintas sobre el carácter no lógico sino emotivo e irracional de una multitud de estímulos, que aquí aparecen yuxtapuestos: la notable germinación imaginativa de corte irracional pone de manifiesto el espesor de la mirada, que enfoca con lente amplificadora un mundo de fuerzas primarias y oscuras. El hecho, además, de que ese absurdo sea "de óptica / excitada" pone énfasis en la luz y recuerda otras referencias intratextuales recurrentes en su poesía (cristal, lago, ventana, espejo...), así como, también, subyuga la mirada, por decirlo así, a cierta erótica del dinamismo, característica que comparte con la noción de "navegar" (“navega el pánico"):

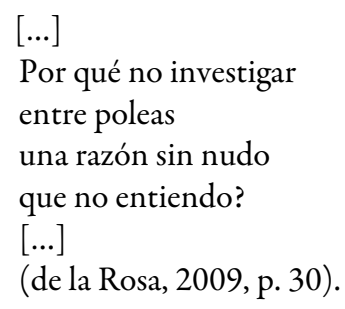

El valor afirmativo de la negación, bastante habitual en nuestro poeta y que también puede apreciarse en Vicente Aleixandre, así como el hecho de que haya "una razón sin nudo" y que esta esté "entre poleas" refuerza nuestra impresión anterior: existe en el poeta la conciencia de que hay que indagar por otros caminos distintos a los del conocimiento habitual, dejando de lado la lógica. Las poleas, círculos en movimiento constante, así como el nudo, esa trabazón que nos impone la razón, se alejan al negarle al poeta el conocimiento. No obstante, esa negación es, en efecto, una afirmación, pero ¿¿de qué? El poeta lo deja, pensamos, bien claro:

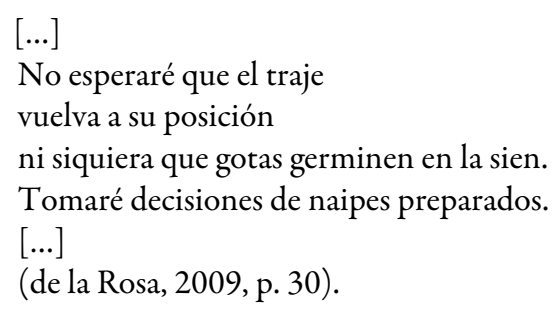

El traje ${ }^{19}$ es signo habitual de lo convencional y cotidiano, de la realidad que se entiende como inmutable. La negación sería aquí el nexo con lo imaginario. La soledad del último verso que hemos transcrito denota ese deseo por lograr la simbiosis entre lo racional (las "decisiones") y el azar ("naipes preparados"). También esto refleja la propia contradicción en que el poeta se encuentra, una contradicción que no es más que otro rumbo para alcanzar metas más lejanas, para dar un mayor alcance a la mirada; es por ello por lo que los horizontes y la proyección de la mirada en la distancia cobran un sentido tan significativo al final del poema, a lo que hemos de añadir una nueva referencia a su hermano, un pintor en ciernes de notable proyección:

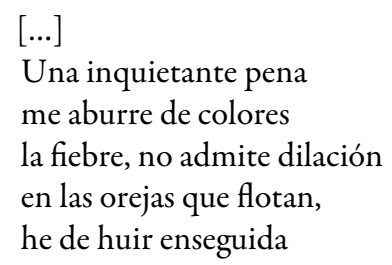




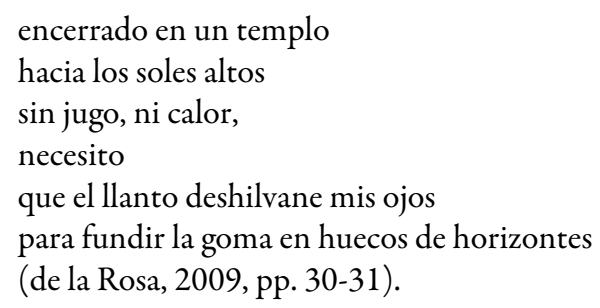

Una y otra vez sentimos en estos poemas una voz profundamente conmovida que en cualquier rincón, dentro o fuera de sí mismo, encuentra un estímulo para desencadenar la escritura. Esto trae consigo todo un imaginario que sumerge al poeta en el mundo natural de su ámbito insular. Esta apelación se da a través de conceptos fundamentales ligados a los elementos (tierra, mar, fuego y aire). Se convertirán en signos conductores de una espiritualidad intensamente agitada. Con todo ello el poeta logra crear un ambiente, una atmósfera de especial receptividad, que podemos palpar en el poema XVI de Íntimo ser. "Veámoslo":

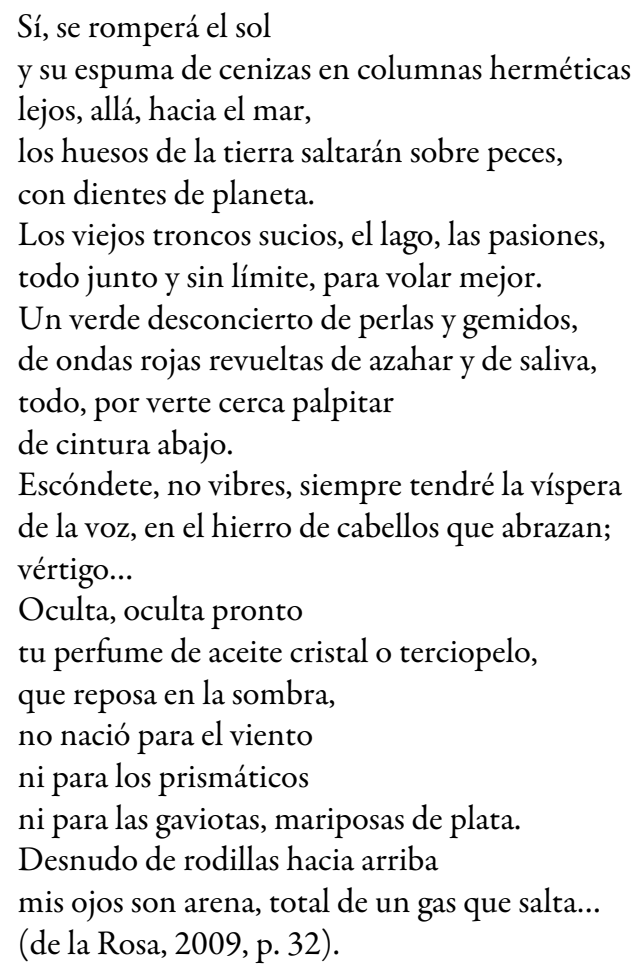

A la creación de este clima contribuye la presencia de diferentes estados ("cenizas", "gas”) de destrucción o aniquilamiento, muy vinculados a su poética ya desde un inicio; también los elementos sensoriales ("columnas", "verde desconcierto", "víspera de la voz", "perfume", "sombra”) que ahogan al poeta. Los sentidos presentes se funden (vista, oído, olfato) y se anulan; son trascendidos hasta llegar, al final, a un estado de comunión con el paisaje, proyección o transposición de un orden vital; pero, junto a esto, lo que más llama nuestra atención es el testimonio que apunta a un rasgo estructural al que ya nos hemos hecho referencia: el poeta como observador. La referencia a la lejanía, a la distancia, otro vocablo clave para José de la Rosa, en la primera estrofa ("en columnas herméticas / lejos, allá, hacia el mar") enlaza con este postulado, al que hemos de agregar la indeterminación en la que se sitúa lo observado, elemento que podemos vincular fácilmente con la importancia de la imaginación ${ }^{20}$ : si lo real está poco claro es porque el poeta necesita buscar refugio en su interior. Las imágenes visionarias de carácter cósmico que aparecen en el poema ("cenizas en columnas herméticas", "los huesos de la tierra saltarán sobre peces" o "un verde desconcierto de perlas y gemidos") no hacen más que dilatar esta premisa. En este sentido, creemos que los dos versos que conforman la segunda estrofa son claves: los viejos troncos sucios -la realidad-, el lago -símbolo que se relaciona con la imagen 
idílica de aquella, en clara referencia a la imaginación-, las pasiones -el mundo interior- se dan la mano "para volar mejor”. Esta defensa de lo irreal como procedimiento poético más acabado del conocimiento -de la verdad- es, en el fondo, lo que todo poeta persigue y queda aquí claramente fundamentada.

Los espejismos, engaños visuales que da el exceso de luz, son propios de los espacios desérticos. El deseo de consolidar -hacer sólido- el movimiento marino y la caída solar hacen que el poeta identifique al sol con un gran espejo -metonímicamente cristal-y al mar con un "desierto azul", en una suerte de proyección de su paisaje interior en el paisaje insular, que se identifica perfectamente con su soledad. Así, el inicio del poema XVII es una amplificatio de este espectáculo lumínico:

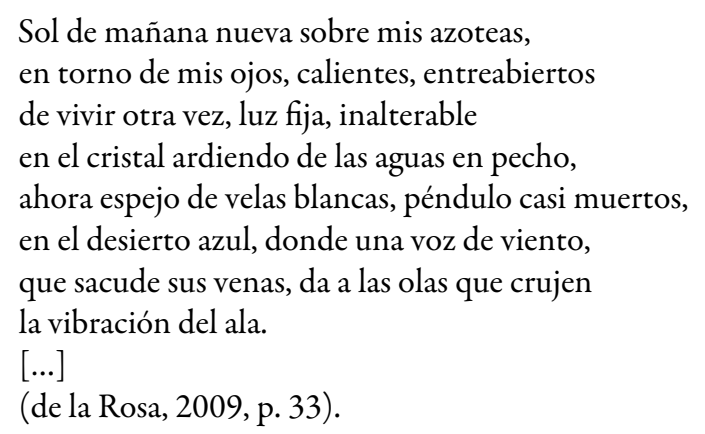

Con adjetivos propios de la primera vanguardia, y que nos recuerdan a su hermano ("mañana nueva") el tema recurrente del poeta-observador que mira el espectáculo de la tarde se sitúa, cronológicamente, también en los últimos años de la tercera década del siglo XX. Fácilmente, situamos este poema en la órbita de los primeros libros de Julio de la Rosa, Domingo López Torres o Pedro García Cabrera, con ese toque neopopularista aprendido de Juan Ramón Jiménez, Rafael Alberti y Federico García Lorca. De todas formas, esta vertiente neopopular no esconde una angustia visceral que, como las olas, va y viene constantemente enturbiando el ánimo del yo poético:

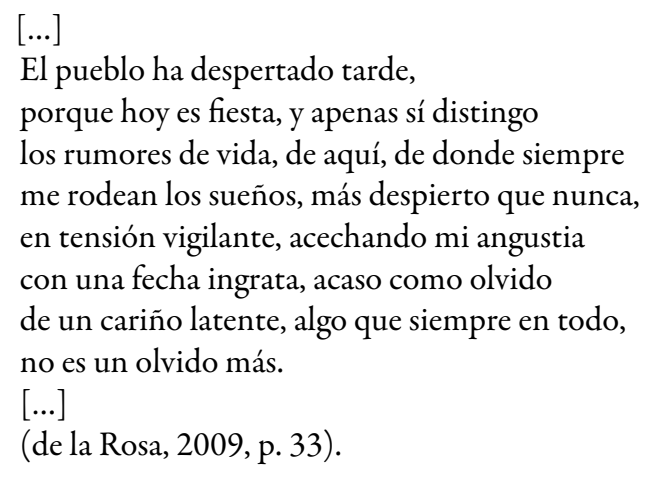

En este fragmento, que nos recuerda al poema de su hermano "Domingo en el pueblo" ${ }^{21}$, esa "fecha ingrata" adquiere claras connotaciones biográficas a las que ya hemos aludido, motivo de esa angustia ya mentada en la estrofa primera. Como el sol, en su camino hacia la plenitud para, en la tarde, ocultarse y dar paso a la noche, el poema sigue un mismo movimiento vertebrador, pues avanza desde la mañana hasta la noche en una especie de antítesis conceptual -y espiritual- que equilibra la alegría del nuevo nacimiento con el sombrío y angustioso dolor íntimo final. Este momento, el de la nocturnidad, es también el de la escritura, a la que se hace referencia metonímicamente:

$[\ldots]$

Son las diez y palpita entre mis pensamientos uno frío y redondo que me hierve en la mano, aquí junto a la frente, encerrada en mis dedos; pensar en ese día, cuando la verde hierva dio al aire sus cabellos en un principio, vida 


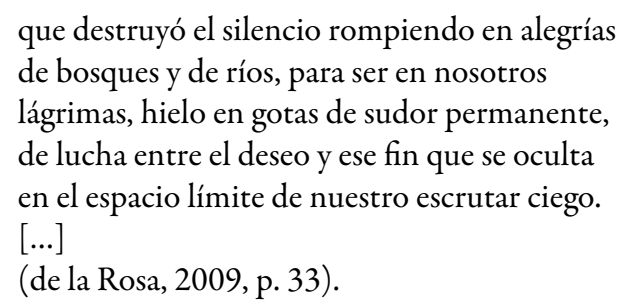

Se dan cita aquí las dos herramientas del poeta: su perfil psicológico y el elemento motor que le permite escribir ("frente" y "mano"). No hemos de dejar de señalar que la metonimia permite al poeta jugar con un mayor abanico de posibilidades y de relaciones entre el término presente y el sustituido (pensamiento e instrumento para la escritura); este recurso, además, refuerza el entramado poético-simbólico de la composición. Así, la muerte de su hermano será, como ya creímos intuir en el poema XIII, el arranque de ese "escrutar ciego" del poeta, una incesante lucha entre el deseo y la realidad. Poéticamente, ese deseo está representado en el movimiento solar y marino, pero son el "vivo dolor" y la angustia los que triunfan, representados en la tierra con su quietud y frialdad, mortal estatismo. Esta es la conclusión que emana al final de la composición:

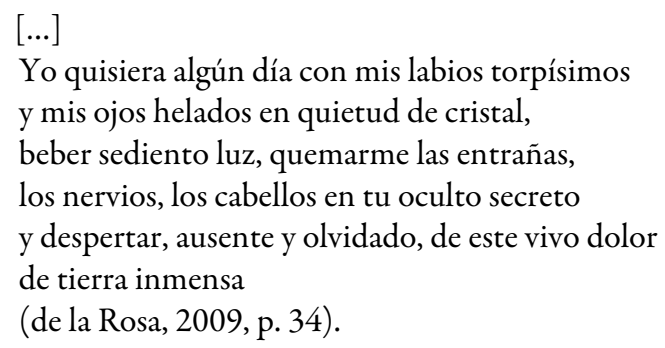

Espacio y tiempo están altamente presentes con múltiples adverbios y locuciones preposicionales; ese deseo por señalar y situar (deícticos, preposiciones y demostrativos) no hace más que incidir -recordémoslo- en la noción de espacio como reino de la mirada: es un intento por concretar lo irracional, las abstracciones. La abundante presencia de sustantivos, la mayoría abstractos en cuanto a la percepción del referente, ensalza su mundo interior, el mundo poético e irreal. A su vez, ese amontonamiento de sustantivos hace que estos pierdan su valor habitual, quedan ahogados, lo cual ayuda a crear un clima asfixiante en extremo.

El hecho de aunar varios sentidos (la vista y el oído) en algunos poemas hace que el mundo sensorial se contraiga, con lo que se rompen los límites perceptivos y afloran los deseos ocultos en los rincones de la interioridad, un mundo irreal donde lo visual suena y lo sonoro tiene color. Esta confusión es otro medio para fortalecer la base simbólica poética. Así ocurre en el poema XVIII:

\footnotetext{
De carmines se tiñe el viento cuando llora; son los rumbos viajeros en el espacio roto, rumores que me llegan de todos los rincones, envueltos en un ruido de metales...

Y no sé si el color son mis ojos que saltan buscando en las campanas, una soledad nueva, cuando vienen sus voces a colgarse en mi oído, y las nubes remotas - una sombra abrazada, una sombra abrazada confundida con otra, como hermanas gemelas; lejos ya las siluetas de las palmas en vilo, a tornasol medidas como extraños fantasmas, augurando al sonido un resplandor lejano, devenir entre llamas y final luto impávido. $[\ldots]$ (de la Rosa, 2009, p. 35).
} 
Es así como podemos comprender líricamente que salten los ojos, "buscando en las campanas, una soledad nueva" 22 o que "sus voces vienen a colgarse en mi oído"; esto genera imágenes cercanas a la sinestesia, una herramienta estilística que es ideal para proyectar percepciones de dentro hacia fuera.

Junto al sol y al viento, la palmera es otra figura del paisaje que representa, en su melancólico retiro, la propia soledad del poeta. El empleo de recursos de carácter barroco, como el hipérbaton y la antítesis ("devenir entre llamas y final luto impávido”) va dando paso a un cúmulo de visiones ${ }^{23}$ que enaltecen la plasticidad e intensifican el protagonismo de la mirada interior. Esta última hace que todo el entorno llegue a un estado de disolución para ser, nuevamente, construido:

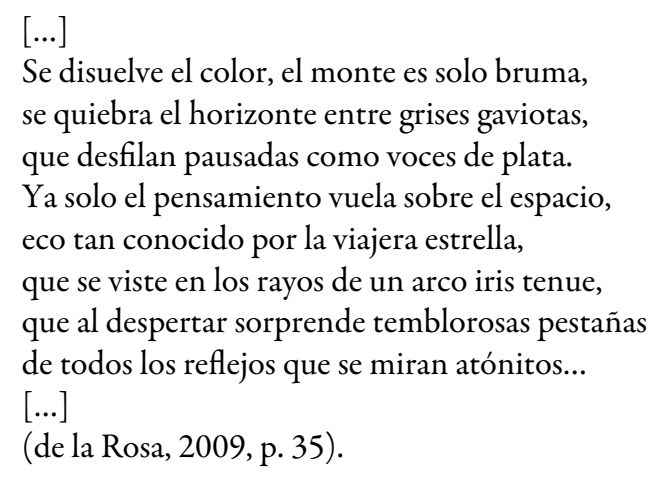

El tránsito de la tarde a la noche es, simbólicamente, la referencia textual al dominio del paisaje íntimo, de la mirada desde dentro. Interesa más el propio devenir como proceso que como medio para llegar a una meta. Ello se refleja en la acumulación de sustantivos, sintagmas y enunciados, muchas veces a partir de yuxtaposiciones, sin transición, sino en movimiento constante. Pensamos que ese interés continuo por la movilidad de la percepción no es más que un reflejo, nuevamente, de su angustia recóndita, que se regenera constantemente.

Así, pues, cierto dramatismo será otro de los caracteres de la lírica constantes de la poética de José de la Rosa. Los versos que cierran este primer poemario contraen lazos con su posterior y principal obra, donde el carácter visionario de la óptica surrealista permitirá al poeta ceñir verbo y torrente interior. En este poema final, los juegos cromáticos entre el sol, el mar y el horizonte esconden rincones en los que bucea el alma atormentada del yo poético. Blancos, grises, azules, carmines, son los colores de su arcoíris íntimo:

No te acerques,

espera que los atardeceres se claven puñales,

que hagan rodar tus cabezas por la oscuridad.

No encerraré tus pueblos en mis ojos,

los dejaré que duerman

en gotas violetas o azul-gris.

Aquella vela, arrugada, y sin ruta,

te la regalaré para tu noche...

De la cuna del valle se ha ausentado la hora,

ya solo eres silueta de color mutilado,

diestramente escondido por las tiras

de desgarrada nieve, que amortaja la niebla

en una procesión de carmines de ala.

¿Qué inútil el sudor, la hiedra, el viento

ante esa placidez de extremidades

que regresen al mar después del día,

qué rubores de luz extraviada

en un genial placer de escamas suaves!

Solo queda una nube,

escuálido avión sin fijo rumbo, 


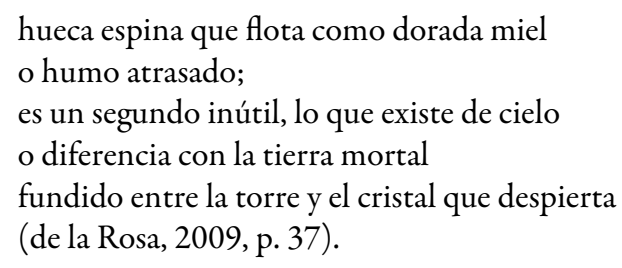

El poeta observa el horizonte ("procesión de carmines de ala"), signo de lo transitorio, con constante traslación, como el ala; observa este entrecruzamiento de sensaciones, pero siempre anclado en la tierra, fija, inalterable, como la muerte. El antagonismo que se genera entre esta realidad desde la que se observa y el deseo, representado en ese tránsito continuo, es lo que da lugar a esa angustia y dolor, que se clavan en el alma del poeta como los pies se hincan en la tierra. Y es que toda esa realidad se ha convertido en intimo ser, que no significa más que la invasión del flujo de la vida interior en todo lo que rodea a la voz lírica. El texto su conjunto de imágenes- zahiere la imaginación, la sensibilidad. Los elementos concretos se convierten en asideros para proyectar y fijar las ensoñaciones de la realidad. Es una proyección cósmica, de fusión con lo natural. Por ello el tono revelador, buscador de la verdad, es el imperante; de ahí la relevante presencia de la negación: poesía de íntimo vértigo del dolor, visiones rotas.

El choque entre elementos simbólicos ambivalentes, extremos del equilibrio, caracterizados por la movilidad, y otros signados por el estatismo, es producto de la exploración del inconsciente que realiza el poeta; la eterna lucha entre la vida, el querer ser -mundo interior- y la muerte, la cruda realidad vivida y el entorno -mundo exterior-, es producto de la insatisfacción vital que busca, como forma para rebelarse, en los sueños lo misterioso y lo fantástico, que no son más que caras ocultas de la realidad cotidiana. Solo la poesía permite un contacto vital con la intimidad, un contacto visceral, medular con el espíritu humano. Lo íntimo se torna espejo de lo infinito y cósmico.

\section{Conclusión}

En Íntimo ser podemos recopilar algunos de los elementos clave en el singular mundo poético de José de la Rosa: la obsesiva presencia de la sombra ${ }^{24}$ como entorno y referente de su proyección, una sombra que es reflejo de su mundo interior, agitado, convulso, lleno de recuerdos; la importancia del poeta como pintor que edifica, con su mirada, su mundo lírico, aniquilado por el dolor de la pérdida de seres queridos (hermano, amigos); los motivos del paisaje insular, siempre presentes, que hace propios como fulgores de su experiencia, sobre la que fragua su desazón creadora. Todo parte, claro está, de su peculiar modo de comprender y sentir el mundo y la propia experiencia lírica, una metafísica del ser y del lenguaje. Todos estos aspectos son los que, creemos, dan lugar a una de las voces líricas más singulares de la época republicana en las islas, cuyo camino creativo se empareja con el de escritores insulares coetáneos y toma, también, como referencia a poetas del 27 , especialmente a Vicente Aleixandre. Su obra lírica posterior, no hará más que corroborar este pensamiento y consolidar ese camino que, partiendo de esquemas tomados de la estética del 27 , ahondará en el vértigo surrealista.

\section{BibLiografía}

Alberti, R. (2000). Sobre los ángeles. Yo era un tonto y lo que he visto me ha hecho dos tontos. [Edición de Cyril Brian Morris]. Madrid: Cátedra.

Aleixandre, V. (1974). Espadas como labios. La destrucción o el amor. (J. L. Cano, ed.). Madrid: Castalia.

Breton, A. (1995). Manifiestos del surrealismo. (6 ed.). Barcelona: Labor.

Cirlot, J. E. (1998). Diccionario de símbolos. Barcelona: Círculo de Lectores.

Cooper, J. C. (2000). Diccionario de simbolos. Barcelona: Editorial Gustavo Gili. 
De la Rosa, J. M. (1966). Desierta espera. Santa Cruz de Tenerife: Gaceta Semanal de las Artes.

De la Rosa, J. M. (29 de octubre de 1977). La República, el Ateneo y Gaceta de Arte III. El Día, p. 30.

De la Rosa, J. A. (1994). Tratado de las tardes nuevas. [Introducción de Isabel Castells]. Las Palmas: Gobierno de Canarias.

De la Rosa, J. M. (2009). Eclipse de círculo. [Edición, epílogo, notas y selección bibliográfica de José Manuel Martín Fumero]. Santa Cruz de Tenerife: Ediciones Idea / La Página Ediciones.

Espinosa, A. (2007). Crimen y otros escritos vanguardistas. (M. Pérez Corrales, ed.) Santa Cruz de Tenerife: Ediciones Idea / La Página Ediciones.

Feria, R. (1988). Stadium. [Edición facsímil con prólogo de Antonio Espina]. Canarias: Viceconsejería de Cultura y Deportes del Gobierno de Canarias.

García Cabrera, P. (1987). Obras completas. (S. de la Nuez, N. Palenzuela y R. Fernández, eds.). Madrid: Gobierno de Canarias.

Gutiérrez Albelo, E. (2007). Poesía surrealista (1931-1936). [Edición crítica de Isabel Castells]. Santa Cruz de Tenerife: Ediciones Idea.

Jiménez, J. R. (1975). Nueva antología. [Estudio y selección de Aurora de Albornoz]. Barcelona: Península.

López Torres, D. (1993). Obras completas. (C. B. Morris y A. Sánchez Robayna, eds.). Santa Cruz de Tenerife: Cabildo Insular de Tenerife.

Martín Fumero, J. M. (2018). Asedios a la poesía surrealista de José María de la Rosa. El caso de Vértice de Sombra. Lectura y Signo, (13), 121-137. doi: 10.18002/lys.v0i13.5671

Martín, S. (1993). José María de la Rosa. [Colección "La era de Gaceta de Arte"]. Tenerife: Gobierno de Canarias.

Morris, C. B. (1988). Una generación de poetas españoles (1920-1936). Madrid: Gredos.

Nuez Caballero, A. (1986). La literatura canaria en los siglos XIX y XX. Teatro, prosa, grupos, tertulias, revistas y 2. Aguayro, (167), 39-41.

Paz, O. (1990). La otra voz. Poesía y fin de siglo. Barcelona: Seix Barral.

Pellegrini, A. (Ed). (1981). Antología de la poesía surrealista. (2 ed.). Barcelona: Argonauta.

Pérez Minik, D. (1975). Facción española surrealista de Tenerife. Barcelona: Tusquets.

Sánchez Robayna, A. (1989). Hacia una perspectiva crítica actual del surrealismo en Canarias. Ínsula, (515), 29-30.

\section{Notas}

1 En la edición de Desierta espera (de la Rosa, 1966), el dibujo que antecede a este poemario es de su hermano Julio Antonio de la Rosa.

2 Íntimo ser, obra terminada en 1936, no se edita hasta 1966 en el volumen Desierta espera, que recoge toda la producción de José de la Rosa hasta ese momento. Esta obra tiene una edición parcial en 2008, bajo el título Eclipse de círculo, que recoge los poemarios Vértice de sombra e Íntimo ser. Dado que ambas ediciones están agotadas, en muchos casos hemos decidido aportar el poema en su totalidad, de forma que, por un lado, ilustre como evidencia documental primera los juicios críticos que realizamos y, por otro lado, se puedan contrastar estos juicios con la lectura directa. Precisamente, tomaremos para citar esta última edición que señalamos, junto al poema o fragmento que tomemos, se incluye la página en que se encuentra.

3 Esta expresión nos recuerda a esta otra de Juan Ramón Jiménez (1975, p. 109) en su poema "Retorno”: "Y...un aroma confuso de fechas y de cifras, / me va, entre luz y sombra, raramente envolviendo...”.

4 Por otra parte, también podríamos considerar que con el adjetivo "tibio" el poeta refiere el valor simbólico del aire como elemento ligado al concepto de creatividad, por su dinamismo.

5 Sabas Martín (1993) habla de la importancia que tuvo para los hermanos de la Rosa la habitación azul de su casa santacrucera; la presencia de este color en este poema puede ser una referencia a este lugar, que pudo adquirir para José de la Rosa un alto valor simbólico y autobiográfico.

6 Ejemplos de poemas con similares características abundan en los poetas canarios de vanguardia: así podemos encontrar ejemplos en Stadium, libro de Ramón Feria (1930/1988), como los titulados “Tu simpatía", "Paisaje” o "La noche”; también en Tratado de las tardes nuevas (1931/1994), de su hermano Julio Antonio de la Rosa, como el número 19, que 
se encuentra en la sección "Poemas varios", en el que se encadenan una serie de breves bosquejos líricos; en fin, podemos añadir que en Líquenes, de Pedro García Cabrera (1928/1987), tenemos casos de poemas breves como los poemas 12 ("Por la calzada celeste”), 15 (“Lo menos me tiene el mar”) o 27 (“¡Papá, papá, que el barquito”).

7 Quizá, tres de los casos más relevantes sean Pedro García Cabrera con su libro Líquenes, de 1928 (1987 versión), Julio Antonio de la Rosa en Tratado de las tardes nuevas (1931/1994) y algunas composiciones, de las pocas que han llegado hasta nosotros, del joven poeta Agustín Miranda Junco.

8 Breton (1995, p. 224), en relación con la importancia de la palabra, del verbo, es muy contundente: "el verbo ha sido elevado hasta el punto de convertirlo en el primer ejemplar de la causa de las causas; por ello, el verbo se encuentra tanto en lo que tenemos como en lo que escribimos como en lo que amamos".

9 Como sabemos, es precisamente Lo imprevisto el título del libro surrealista de Domingo López Torres.

10 Recordemos que ángeles aparecen en las Rimas becquerianas, como en LXXIV y LXXVI. Además, la referencia a Alberti es aquí obligada. Probablemente nuestro poeta fue, como Gutiérrez Albelo, un ferviente lector del poeta gaditano desde sus inicios, de forma tal que, como el autor de Enigma del invitado (1936), quedó fuertemente impactado por su poesía de orientación surrealista en Sobre los ángeles (1929/2000). Como ejemplo emparentado con la poesía de José de la Rosa tenemos el poema "Los ángeles sonámbulos" (2000, p. 120), en el que la ausencia de verbos, como en de la Rosa, suspende el tiempo, lo cual provoca la aparición de la monotonía como pesado lastre:

I

PENSAD en aquella hora;

cuando se rebelaron contra un rey en tinieblas

los ojos invisibles de las alcobas.

Lo sabéis, lo sabéis. ¡Dejadme!

Si a lo largo de mí se abren grietas de nieve,

tumbas de aguas paradas,

nebulosas de sueños oxidados,

echad la llave para siempre a vuestros párpados.

¿Qué queréis?

Ojos invisibles, grandes, atacan.

Púas incandescentes se hunden en los tabiques.

Ruedan pupilas muertas,

sábanas.

Un rey es un erizo de pestañas.

En Enigma del invitado (Gutiérrez Albelo, 2007, p. 81) encontramos esta sugerente referencia:

Un ángel se estiró sobre la mesa,

aleteando, trémulo.

Y yo titubeaba

para recomponerlo.

Unos chorros de añil

salpicaron mi bata de cirujano inepto.

[...]

11 La idea de "romper" se relaciona con la de fragmentar la realidad para multiplicarla (ya en Crimen, de Espinosa, 1934, y en Diario de un sol de verano, de López Torres, 1929). Al romper, se vulnera el principio central, fundamental, de la identidad, con lo que se da carta de naturaleza al papel tanto de la imaginación como de lo irracional, ejes que vertebran el poema. Gutiérrez Albelo (2007, p. 106), en el “Poema 23” de Enigma del invitado, en la parte final enuncia lo siguiente: "Pero al amanecer / -mucho antes de que en la crónica oficial de sucesos-, / me vi multiplicado / en todas las esquinas de aquel barrio sin sueño".

Por su parte, López Torres (1993, p. 67) también insiste en este mismo concepto en su poema no. 4 de Diario de un sol de verano:

LOS ESPEJOS se hacen trizas

en verticales de piedra.

Se descomponen

cuerpos duros de montañas

en triángulos biselados.

Yo, roto, multiplicado. 
12 Recordemos que para Juan Ramón Jiménez (1975, p. 16) el instinto “es todo ojos”.

13 De esta misma opinión es Antonio de la Nuez Caballero (1986, p. 41), al afirmar que, junto a Juan Ismael y Pérez Minik, José de la Rosa habría mantenido, también, una "posición surrealista”.

14 Esta técnica comparativa, muy surrealista, es la que se aprecia, por ejemplo, en el poema "El cuadrado de la hipotenusa”, de Benjamin Péret (citado en Pellegrini, 1981, p. 207) (la cursiva es nuestra):

$[\ldots]$

duro como una escollera

cuando

en la lluvia de tinta que me atraviesa con espejos

tus ojos mágicos como un árbol degollado

gritan en todos los tonos [...].

15 Ciertamente, el valor asociativo de la palabra expande infinitamente su significado con el surrealismo; así C. B. Morris (1988, p. 218), dirá que el surrealismo sí valió "para que se explorara la fantasía y se liberara a las palabras de sus ya gastadas asociaciones $[\ldots]$ ”.

16 “Los pájaros pierden sus formas, después de perder sus colores” según Breton (1995, p. 81). El motivo del pájaro o las aves está muy presente en la pintura y poesía surrealistas, como por ejemplo en "Pájaro Pi" o "Pájaro-flor”, de Eugenio Granell, "La creación de las aves", de Remedios Varo o, también, en el Lop-Lop de Max Ernst. Algunos poetas surrealistas que nos brindan ejemplos de este tema son Robert Desnos ("Destino arbitrario"), Aimé Cesaire ("Milibares de la tormenta"), Raymond Queneau ("Lámparas agotadas") o Francis Picabia ("Oasis"). Por último, en los escritores insulares hemos hallado ejemplos en Enigma del invitado (Gutiérrez Albelo, 2007, p. 82), como en el fragmento 7 (“pájaro del sueño”, expresión que también aparece en el poema de Dársena con despertadores, de Pedro García Cabrera (1987, p. 95), titulado “Habla el pájaro del sueño") y en Crimen (Espinosa, 2007, p. 29) (“un gran pájaro blanco”, en “Ángelus”) podemos encontrar referencia a este motivo.

17 En José de la Rosa la irrealidad del deseo, que no se puede contrastar, hará que crezcan las ramas de lo irreal en la escritura. Esta premisa es un motivo inherente a su poética, una forma más de ahondamiento.

18 Vicente Aleixandre (1974, p. 193) llama "moneda lírica" a la luna en su poema de "Verbena".

19 La prenda es un elemento muy surrealista que, por ejemplo, aparece en Gutiérrez Albelo en su poema "la cita” (2007, pp. 38-39), de Romanticismo y Cuenta Nueva o los fragmento 10 y 14 de Enigma del invitado (2007, pp. 86 y 92). También en Crimen (Espinosa, 2007, pp. 21-22), con "Hazaña del sombrero" aparece este motivo; en otros textos surrealistas de Espinosa como "El traje de novio" (Espinosa, 2007, pp. 71-73) hay nuevamente referencias a las prendas.

20 Para Breton (1995, p. 293) “es preciso conservar la libertad de la imaginación poética”.

21 Este poema es el undécimo viraje lírico de Tratado de las tardes nuevas (1929) (de la Rosa, 1994, pp. 96-97); poemas de similar tesitura neopopular en Julio Antonio de la Rosa son "La curandera" o "Cañita de manzanilla", de Poemas varios (1927) (1994, pp. 29-32) o, también, "Poema de la gallinita ciega” y "Poema de la pájara pinta”, que se encuentran en el apartado Poemas ingenuos (1928) (1994, pp. 67-69).

22 El ojo es uno de los grandes temas del surrealismo; pensemos en Un perro andaluz, de Luis Buñuel, "Engaño a los ojos”, de Rene Magritte o, también, “Ojos sobre la mesa”, de Remedios Varo y “Mirada del amor” o "El paisajista y sus ojos”, de Juan Ismael. En la poesía surrealista se pueden encontrar muchos poemas que contienen este motivo; nosotros citamos los siguientes a modo de muestra: "Sol serpiente”, de Aimé Cesaire, "En el corazón de mi amor", de Paul Eluard, "Últimos cartuchos", de Philippe Soupault o, en fin, "Sentido plástico", de Malcolm de Chazal. En la literatura surrealista insular, Agustín Espinosa (2007, p. 13) en Crimen afirmaba que "Yo ya solo vivo para un estuche de terciopelo blanco, donde guardo dos ojos azules...”. También Gutiérrez Albelo (2007, p. 77), en Enigma del invitado, emplea el motivo de "los ojos", por ejemplo, en el segundo fragmento ("Se me esconden los ojos / rondando para adentro"). La autonomía ocular, con la que se acentúa el valor del poeta como intérprete y espectador, es otro de los signos de Íntimo ser. Hemos de agregar que la independencia de ciertos elementos del cuerpo humano, como los ojos, es una forma de otorgarles un mayor grado de pureza o, lo que es lo mismo, un valor verdadero.

23 Para Breton (1995, p. 20) "las alucinaciones, las visiones, etcétera, no son fuente de placer despreciable".

24 Estos comentarios nos traen a la mente los cuadros Despedida y Fenómeno, de Remedios Varo. 